\title{
Foreign Bank Penetration of Newly Opened Markets in the Nordic Countries
}

\author{
Engwall, Lars; Marquardt, Rolf; Pedersen, Torben; Tschoegl, Adrian E.
}

Document Version

Final published version

Publication date:

1999

License

CC BY-NC-ND

Citation for published version (APA):

Engwall, L., Marquardt, R., Pedersen, T., \& Tschoegl, A. E. (1999). Foreign Bank Penetration of Newly Opened Markets in the Nordic Countries. Department of International Economics and Management, Copenhagen Business School. Working Paper / Department of International Economics and Management, Copenhagen Business School No. 2-1999

Link to publication in CBS Research Portal

\section{General rights}

Copyright and moral rights for the publications made accessible in the public portal are retained by the authors and/or other copyright owners and it is a condition of accessing publications that users recognise and abide by the legal requirements associated with these rights.

Take down policy

If you believe that this document breaches copyright please contact us (research.lib@cbs.dk) providing details, and we will remove access to the work immediately and investigate your claim. 


\title{
Foreign bank penetration of newly opened markets in the Nordic Countries
}

\author{
Lars Engwall \\ Department of Business Studies \\ Uppsala University \\ S-751 20 Uppsala \\ Sweden \\ email: lars.engwall@fek.uu.se \\ Rolf Marquardt \\ Swedish Bankers Association \\ Stockholm, Sweden \\ email: rolf.marquardt@bankforeningen.se \\ Torben Pedersen \\ Institute of International Economics and Management \\ Copenhagen Business School \\ Nansensgade 19, DK-1366 \\ Copenhagen, Denmark \\ email: tp.int@cbs.dk \\ Adrian E. Tschoegl* \\ Department of Management SHDH 2000 \\ The Wharton School \\ University of Pennsylvania \\ Philadelphia, PA 19104-6370 \\ email: tschoegl@wharton.upenn.edu
}

March 1999

Please do not cite or quote without the authors' permission.

*Corresponding author

JEL Classification: F2, G2, \& N2

Keywords: entry, foreign banks, Nordic countries 


\title{
Foreign Bank Penetration of Newly Opened Markets in the Nordic Countries
}

\begin{abstract}
$\underline{\text { Abstract }}$
The opening to foreign banks in Denmark, Finland, Norway and Sweden provides us with an opportunity to study entry, survival and success in a situation where the entrants were subject to the liability of foreignness but not the liability of newness. We find that despite low survival rates, on balance the entrants gained market share (in terms of the assets of the banking system) over time. Our results for the role of time, links to the home market and problems facing domestic competitors were strongly in accordance with expectations in the cases of Denmark, mixed or indeterminate for Finland and Norway, and strongly opposite in the case of Sweden. Lastly, our results are broadly consistent with the StiglitzWeiss argument that new entrants, in this case foreign banks, buy entry by accepting worse lending risks.
\end{abstract}

\subsection{Introduction}

In 1971 Denmark deregulated its domestic banking markets and the entry of foreign banks. Only one foreign bank entered initially and the number of foreign banks grew slowly over time. Finland opened next (1978) but no foreign banks entered until four years later when further deregulation made entry attractive. Norway (1984) and Sweden (1985) opened more than a decade after Denmark and a number of banks all entered at once. Today, after falling from its peaks, the number of foreign banks and their share of each country's banking system assets is recovering. In some cases, 
especially when acquisitions of domestic banks are involved, the number and market share represents a new peak.

The issues of entry, survival and success, especially in the context of foreign direct investment (FDI) are important ones to corporate strategy and these four examples give us an opportunity to study a special type of entry situation. The opportunities for the foreign banks did not develop slowly with the evolution of an economy or a technology but suddenly (though with forewarning) when governments removed their barriers. In all four countries, opening to foreign banks accompanied a more general deregulation that resulted in competitive turbulence. The authorities welcomed the foreign banks and perhaps even sought them out to add competition and new capabilities to the domestic market. However the authorities were also concerned about the effect of the entrants on monetary policy, credit control and the soundness of the existing domestic banks.

The foreign entrants were particularly well-adapted to take advantage of the openings. They were offshoots of their parent banks: large, internationally well-known, existing organizations. As such they were not subject to many of the hazards facing totally new firms such as the need to establish reputations in order to have access to capital, or to being particularly vulnerable to stochastic shocks because of their small size. However they were still subject to the liability of foreignness.

Our objective is to determinants of the foreigners' market share of the assets of the banking system as a whole, not the survival and success of individual banks. The literature on the evolution of the market share of foreign banks is at best slim. Still, the literature does suggest some hypotheses that are amenable to testing. We relate the foreign banks' market share in each of the four countries to a time trend, to each host 
country's trade balance, and to the banking system's loan loss experience. The first variable captures learning and selection. The second proxies for access to business related to the foreign banks' access to their home markets. The last captures the affect of a possible crisis-induced lack of competitiveness of the host-country banks.

In Section 2 we discuss the regulatory and economic environment that the foreign banks faced in the Nordic countries at entry and after. We also present the basic data on the development of the foreign bank sector in Denmark, Finland, Norway and Sweden. In Section 3 we discuss the limited literature on the market share of foreign banks, and formulate three hypotheses regarding the determinants of the foreign banks' share of the assets of the banking system. In Section 4 we present the results of testing our model. Section 5 concludes the paper by comparing and contrasting the experiences of the foreign banks in the four environments and pointing out some limitations of the analysis.

\subsection{The Nordic case}

\subsection{The environment facing the foreign banks}

Since at least 1920, Finland, Norway and Sweden had forbidden foreign banks to open branches (Wallenberg c.1920). Denmark's prohibition apparently came later. The hostility to foreign banks in the Nordic countries was consistent with policies in other developed countries with governments oriented towards social welfare (Tschoegl 1985). For example, Australia, Canada and New Zealand, among many others, also restricted the entry of foreign banks after World War II. These policies of closure, though they had persisted for decades, eventually collapsed in the 1980s as a philosophy of deregulation, including the removal of barriers to entry, swept the world (for Sweden see Engwall 
1994a \& 1997). At first, the Nordic countries only permitted foreign banks to enter with de novo subsidiaries or at most small shareholdings in existing domestic banks (OECD 1984). As Engwall (1992) points out, governments prefer subsidiaries to branches as subsidiaries give the governments more control over solvency. However banks prefer branches as branches are less costly and more flexible. By the mid-1990s, all four permitted foreign banks to enter with branches. In Finland, Norway and Sweden, since 1990 or so, the authorities have also permitted foreign banks to acquire domestic banks.

The opening to foreign banks was part of a general deregulation of the domestic markets in the Nordic countries that increased competition and may have resulted in some efficiency gains. When Berg et al., (1992) examined productivity in Norwegian banks over the period 1980-1989, they found that productivity appeared to regress prior to deregulation and then grow rapidly afterwards. After deregulation, the range between the most and least productive bank shrank; this shrinkage appeared to have been the result of the larger banks reducing their deficiency vis-à-vis the smallest banks. Shaffer's (1994) cross-country study using data from 1979 to 1991, showed Norway and Sweden to have a highly competitive banking system without excess capacity; his study identified the existence of market power in Sweden and some excess capacity in Finland.

Berg et al., (1993) also compared banking efficiency in Finland, Norway and Sweden in 1990; the average Norwegian bank was more efficient than the average Finnish bank but less efficient than the average Swedish bank. Earlier, Rinde (1986) too had found that Norwegian banks were not less efficient than those in other OECD countries though Swedish banks did seem slightly more efficient. 
The studies by Rinde (1986), Berg et al., (1992), Berg et al., (1993) and Shaffer (1993) essentially predate the loan losses that devastated the banking systems of the Nordic countries, among others, in the early 1990s. Møller and Nielsen (1995) suggest that the banking crisis in the Nordic countries really consisted of four different crises. However, the evidence is the crises in the Nordic countries were part of a worldwide phenomenon. A key factor was the property boom that swept across a number of countries in the late 1980s.

Ball (1994) suggests two primary causes for the boom. First, technical change in key service industries led to an upsurge in demand for buildings from the mid-1970s onward. Second, deregulation increased credit availability. Monetary authorities, attempting to rein-in the credit expansion, ended the boom. Bartholomew (1994) reports that deflation of real estate values hit banking systems in Canada, Denmark, Finland, Norway, Sweden and the United States. Ball (1994) adds Australia, the UK and Japan to the list. Reflecting on the experience of the US and Japan, Kindleberger (1995) has an insightful paper on the difficulty that asset inflation poses for monetary policy. In the Nordic countries, the authorities tightened monetary policy and required their banks to raise their loan loss reserves. Together, these measures brought about banking crises in all four countries.

Overall, loan losses at the commercial banks were less severe in Denmark and Finland than in Norway and Sweden (Tables 1-4). However, rank-orderings of countries are sensitive to definitions. Caprio and Klingebiel (1996) do not list Denmark among their cases of bank crises, but estimate recapitalization costs as a percent of GDP at $8 \%$ for Finland, 4\% for Norway, and 6\% for Sweden. 
All four Nordic countries saw the number of domestic banks shrink in the 1980s and into the 1990s. The entry of foreign banks temporarily increased the numbers but the foreign banks too saw their numbers fall. Only Sweden is now seeing an upturn in both the number of foreign and domestic banks. Against the above background we will now analyze the development in the four countries one by one, in the order of deregulation, i.e. Denmark (1971), Finland (1978), Norway (1984) and Sweden (1985), which fortuitously is also the alphabetic order (at least in English).

\subsection{D enmark}

Until the early 1960s, agriculture was the cornerstone of the Danish economy. Hence there was little need for banks with a large lending capacity. Thus in the late 1950s, Denmark had about 160 private banks and about 475 savings banks (Østrup 1989). As Denmark's developed industrially, the need for financial services grew dramatically. In step with this development, the large banks began to acquire smaller ones, and small local banks merged to form regional banks.

Accession to the EEC in 1972, led Denmark gradually to deregulate, mainly as consequence of the implementation of various EU directives. Deregulation introduced a period of increasing competition, mergers, growing international activities and crossing of demarcation lines among financial institutions (Otholm et al. 1994).

Mergers, due in part to the large loan losses of recent years, have reduced the number of commercial banks to 70 now (Table 1). Still, despite the losses, no banks required government rescue and the banking system as a whole did not require a government 
guarantee. The system owes much of its stability to regulators who required more capital than was the case elsewhere.

Two mergers in late 1990 created two, almost equally-sized nationwide banks, Den Danske Bank - now the largest bank-and Unibank, that dominate the market. There are also nine medium-sized banks, numerous small local banks, and seven foreign banks. In 1988, the top two banks had $40 \%$ of all banking system assets and the top four banks had $62 \%$. In 1995, the respective shares were $62 \%$ and $83 \%$.

All banks are nominally universal banks. Since the 1960s, the major banks have also increased the volume of their international business and have established branches and subsidiaries abroad (Vastrup 1983). Competition within the banking sector is stiff and the banks have developed sophisticated products for both retail and corporate customers.

In advance of accession to the European Economic Community, in 1971 Denmark became the first Nordic country to open to foreign banks by permitting them to open subsidiaries. However, American Express was the only entrant. In 1975, Denmark further deregulated entry by permitting foreign banks to establish branches of the parent. Citibank entered and so did Chase Manhattan. Still, the rate of entry was slow. The late 1960s and early 1970s was only the beginning of a world-wide expansion in foreign direct investment in banking that peaked in the late 1980s or early 1990s (Choi et al., 1996); as a result, the number of foreign banks in Denmark did not reach 7 (the number of immediate entrants into Norway in 1985) until 1983. The number of foreign banks peaked at 9 in 1986 and has fallen since. The foreign banks' share of domestic banking system assets peaked in 1982. Unfortunately for our analytic purposes, the government changed its reporting 
regulations in 1990; hence from 1991 on we no longer have asset data for branches of foreign banks.

Only one foreign bank entered via acquisition; Westdeutsche Landesbank acquired Standard Chartered's subsidiary. Denmark applies the same rules to greenfield operations and acquisitions; even so, hostile acquisitions are very difficult to accomplish. The regulation that no owner of a bank may vote more than $5 \%$ of all votes at the shareholders' annual meeting effectively blocks hostile takeovers. The authorities merged small Danish banks facing difficulties into large domestic banks rather than offering them to foreign banks. In fairness, it is not clear that any foreign banks would have been interested in acquiring troubled small banks.

One unique entrant was Islamic International Bank, a subsidiary of Islamic International Bank of Bahrain. The parent reportedly established the subsidiary in 1983 to serve the needs of devout Moslems in Denmark and Danish companies doing business in the Middle East. The bank changed its name to Faisal Bank in 1993 but has since closed down (Finans and Samfund 1995).

Until the end of the 1980s it was American-owned banks that dominated the ranks of the foreign banks; now it is European-owned banks that dominate. In 1991, Chase Manhattan closed its branch. The branch served the needs of Chase's US corporate clients with operations in Denmark and Chase decided that it could service these customers equally well and less expensively from its London branch (Børsen 1992).

The foreign banks are small and specialize in providing services (including loans) to medium to large firms. A recent inquiry among Danish companies found that $42 \%$ of the Danish companies surveyed used foreign-owned banks. None of the companies used a 
foreign-owned bank as the main bank, but many companies use them as the second or third bank and for specialized financial activities. The same inquiry showed that the Danish companies more often were working with the European headquarters (typically in London) than with a smaller Danish branch.

The foreign banks do have a larger share of some niche markets. The Ministry of Industry (1992) estimates that foreign banks have a market share of around 10\% in services such as cash management and foreign exchange. Currently Handelsbanken, which has three branch offices, is the only foreign bank active in retail banking (Swedish Banker's Association, 1998). Lastly, over the period for which we have data, the rank, among all banks in Denmark, of the largest foreign bank appears to have risen.

\subsection{Finland}

In Finland, deregulation began in 1978 and bank lending increased sharply thereafter. The number of domestic banks did not shrink but neither did it increase until the early 1990s, precisely as the economy ran into severe trouble, due in part to the collapse of the Russian economy in 1991. Exports from Finland to Russia fell from about 25\% of exports to about 3\%. This caused a fall in Finland's GNP and hence an increase in the ratio of the banks' loan losses to GDP.

During the crisis, the government had to take over Skopbank, the $3^{\text {rd }}$ largest bank; the two largest banks survived but merged in 1995. The number of banks, both domestic and foreign, has shrunk from the peak in 1991, despite further foreign entry (Table 2). Overall, the Finnish market has become highly concentrated; in 1996, the two largest banks accounted for $60 \%$ of total system assets; the four largest accounted for $69 \%$. 
Hambros Bank (1973) and Citibank (1977) became the first foreign banks to establish a presence when they each opened a representative office. In 1979, the Finnish government authorized foreign banks to establish subsidiaries, but it took further deregulation and relaxation of exchange controls in 1982 before foreign banks were willing to enter (Pauli 1984). Then Citibank, Chase Manhattan and Banque Indosuez established subsidiaries. Banque Indosuez's entry was an 85-15 joint-venture with Postipankki. In 1984, the government used the foreign banks to break the domestic banks' agreement to control interest rates (Rautava 1994). Between 1983 and 1984, several Scandinavian banks opened representative offices in Helsinki: Skandinaviska Enskilda Banken (SEB; 1983); Union Bank of Norway (1984); Sparbankernas Bank Sweden (1984); Fællesbanken for Denmark (1984) and Svenska Handelsbanken (1984). In 1986, Chase Manhattan sold its subsidiary to PK-banken of Sweden (now MeritaNordbanken), and in 1988 Gotabanken (now part of MeritaNordbanken) opened a representative office. Handelsbanken opened a subsidiary in 1990 which it converted to a branch when the government authorized branches in 1991. Midland Bank and Banque Indosuez also converted their subsidiaries to branches (Savela and Herrala 1992) though Midland closed its branch shortly thereafter. In 1994, Nordbanken withdrew but in 1995, SEB opened a branch. Handelsbanken bought Skopbank to become the fourth largest bank in Finland and the largest foreign bank. In 1997, SEB added Ane Gyllenberg, an investment firm but sold Ane Gyllenberg's stock brokerage to Den Danske Bank in 1998. Also in 1997 Merita Bank and the Swedish Nordbanken merged into MeritaNordbanken, which is now the largest banking group in Scandinavia. Lastly, leadership among the foreign banks passed from an American to an English bank and then to a Nordic one. 


\subsection{N orway}

Norway deregulated in 1984; that year saw the founding of the first new domestic bank since the end of World War II, and others followed. At the same time, some domestic banks merged. Also, Ongena and Smith (1997a) provide evidence that Norwegian companies listed on the stock exchange reduced their number of bank relationships as deregulation progressed. Loans outstanding doubled as banks pursued market share (Lindblom 1994). Already by 1987, the Norwegian banks' loan loss provisions had begun to rise markedly. (An additional factor beyond increased risk taking was the government's introduction of stricter accounting standards.) In the late 1980s, several smaller domestic banks did fail or underwent forced mergers. In Norway the crisis peaked a year or so before the peak in the other Nordic countries (Koskenkylä 1994), perhaps because the fall in oil prices in 1986 hurt the Norwegian economy but helped most other major economies.

The first and third largest banks (Den norske Creditbank and Bergen Bank) merged in 1990 to form Den norske Bank (DnB). Shortly thereafter the government was forced to acquire DnB, Christiania Bank og Kreditkassen (CBK) and Fokus Bank, the then second and third largest. The government reprivatized Fokus, but retains substantial ownership in DnB and CBK. In 1980, the two largest banks accounted for $43 \%$ and the four largest for $71 \%$. In 1996, the two largest banks accounted for $60 \%$ of banking system assets and the four largest accounted for 77\% (Norwegian Commercial Banks 1981 and 1997).

In 1985, seven foreign banks established subsidiaries in Norway; ultimately the number of foreign banks in Norway peaked at nine before declining and then returning to 
the present eight (Table 3). Overall, the foreign banks' market share has grown since entry. Interestingly, Ongena and Smith (1997b) report that the number of relationships with foreign banks reported by Norwegian companies declined from 24 in 1979 to a low of 5 in 1988, and then picked up a little as the banking system ran into trouble.

Norway started to permit foreign banks to acquire troubled domestic banks in 1990 as the domestic banking crisis peaked. In 1990, Svenska Handelsbanken, the $21^{\text {st }}$ ranked (and $3^{\text {rd }}$ ranked foreign) bank in 1989 , acquired Oslo Handelsbanken, the $14^{\text {th }}$ ranked bank. Together, the banks would have ranked $12^{\text {th }}$ in 1989 . Also in $1990, \mathrm{BNP}, 5^{\text {th }}$ among foreign banks in 1989 and $23^{\text {rd }}$ overall, acquired Kjøbmandsbanken, the $20^{\text {th }}$ ranked bank. Together the two would have ranked $14^{\text {th }}$ in 1989 . Handelsbanken continued its expansion through acquiring Stavanger Bank in 1991 and parts of Oslobanken in 1993. Had the Norwegian banking system not been in a state of crisis it is unlikely that the Norwegian government would have readily approved the mergers. Without the mergers it is arguable that the foreign banks' market share would have grown to its present level.

In 1993 Norway acceded to the European Economic Area and agreed to liberalize further its regulations on entry. In 1994, Norway issued regulations authorizing foreign banks to establish branches. Citibank, Chemical Bank and Handelsbanken converted their subsidiaries to branches of the parent and SEB opened a branch. In 1999, Den Danske Bank acquired Fokus Bank, in the process both outbidding Handelsbanken and disrupting the government's plan to merge Fokus with CBK and Postbanken. Lastly, the rank amongst all commercial banks in Norway of the largest foreign bank has improved. As in Denmark and Finland, leadership has passed from an American bank to a Nordic one. 


\subsection{Sweden}

In 1986, Sweden became the last of the four Nordic countries to deregulate. The number of domestic banks in Sweden initially fell. The $3^{\text {rd }}$ and $4^{\text {th }}$ largest banks, Gotabanken and Nordbanken, were the result of mergers that arguably exacerbated the maintenance of internal controls. With deregulation credit also expanded, leading to loan losses (Engwall 1994 \& 1997). Eventually the government had to take over and merge the two, after having first transferred the worst of their assets to a so-called "bad bank." Of the large banks only Svenska Handelsbanken emerged unscathed (Wallander, 1994).

One of the largest new domestic banks is the result of the creation of commercial banks out of the merger of savings banks and cooperatives. Swedbank is the result of the 1992 merger of the ten largest savings banks and its conversion to a commercial bank. Similarly, all the savings cooperatives joined to form Föreningsbanken. In 1997, Swedbank merged with Föreningsbanken into Föreningssparbanken. A number of near banks have decided to become banks; changing technology, especially the variety of forms of electronic banking, have made it possible for banks without extensive branch networks nevertheless to compete with the large banks for retail customers. Lastly, the largest banks continue to grow by merger. In 1997, Handelsbanken acquired Stadshypotek, Sweden’s largest mortgage lender, to become the largest bank in Sweden.

Overall, the number of foreign and domestic banks is growing again though the net number represents the outcome of a race between entry and merger. In 1986, before deregulation, the two largest banks accounted for $37 \%$ and the four largest accounted for $60 \%$ of banking assets (Statistics Sweden).By 1996, the proportions are $51 \%$ and $82 \%$. 
When Sweden permitted foreign banks to establish operations, thirty-some foreign banks already had representative offices there. Of the 14 that applied for permission to establish a subsidiary, 12 received it. Banque Indosuez of France and Postipannki of Finland, entered via a joint-venture. Only two entrants included retail banking in their strategy. Kansallis-Osake-Pankki and OKOBANK, both of Finland, targeted the 400,000 or so Finnish immigrants in Sweden. Among the foreign banks, Midland and ABN AMRO have been particularly active, especially in non-bank financial services. ABN AMRO bought one of the largest Swedish stock brokerage companies and it and Midland both established finance companies.

Anticipating accession to the EU, in 1990, Sweden finally permitted foreign banks to open branches. Six foreign banks converted their subsidiaries. Postipankki and Banque Indosuez wound up their joint venture in 1992, with Banque Indosuez establishing a branch instead. In 1991, Sweden permitted foreign banks to acquire Swedish banks. To date only two cross-border deals have taken place, both in 1997. The first was Den Danske Bank's take-over of Östgöta Enskilda Bank. Östgöta is a provincial bank with an extensive network in southern Sweden, a region close to Denmark that has drawn both Danish companies and individuals. The second is the merger between Finland's Merita Bank and Sweden's Nordbanken. There is also an agreement between Unibank and the Postgirot (the Swedish state-owned post company) that gives the Danish bank access to Postgirot's more than 1,000 local post offices.

After the initial rush in 1987, the number of foreign banks then essentially declined; however since 1994, the number of foreign banks in Sweden has more than doubled (Table 4). Almost all the recent entries have taken the form of branches. GE Capital is an 
exception; it acquired and merged three finance companies and in 1997 received a banking license. Unlike the situation in the other three Nordic countries, the largest foreign bank in Sweden has always been a European or a Nordic bank.

\subsection{The general development of the foreign bank sector}

In all four Nordic countries, even where the market share of the foreign banks as a whole currently is below its peak, individual foreign banks have done well. In each country, the ranking among all banks of the largest foreign bank has increased. Foreign banks gained the largest market share in Finland and Norway, but those foreign banks that made the most progress did so by acquiring local firms. Only Denmark has been immune, due probably in large part to the impediments to cross-border mergers and acquisitions, and the lack of a crisis large enough to force the issue.

In all four countries the nationality of the largest foreign bank has changed as well as the identity. If we take the nationality of the largest bank as an indicator, we can detect three eras. 1970 to the mid-1980s was the American era. The mid-1980s to the early 1990s was the European era. In Sweden, the last to liberalize, the US never provided the largest foreign bank. The mid-1990s has seen the start of a Nordic era.

Some US- and European-owned banks have decided to serve the Nordic market from other locations in Europe. They are closing their branches without, however, abandoning their activities in the Nordic countries. They can exploit scale economies by centralizing their staff in fewer locations without at the same time losing all their Nordic clients. The remaining foreign-owned banks are expanding the scope of their activities. As far as entering the retail market is concerned, the Nordic owned banks have an advantage 
because of the language, the similarities in culture and the common structure of the Nordic societies (Nordström and Vahlne 1994).

The mid-1990s are seeing the emergence of a Nordic strategy among the Nordic banks. Now, many of the Nordic banks are penetrating each others' markets. Deregulation has had both direct and indirect effects. As the Nordic countries deregulated entry, and especially when they permitted the operation of branches, they made entry easier for smaller banks. Jacobsen and Tschoegl (1999) also argue that the deregulation of entry undermined the Nordic consortia that the largest Nordic banks had formed and that incorporated explicit or implicit agreements among the members not to enter each other's markets. DnC was the first leader among the foreign banks when Sweden opened but withdrew in 1990 when, as a consequence of a merger with Bergen Bank, it became part of Scandinavian Banking Partners (SBP; Jacobsen and Tschoegl 1999). The effective demise of SBP in 1994 freed DnB, SEB, MeritaNordbanken (ex-Union Bank of Finland), and Unibank to enter each others' markets.

\subsection{Market shares of foreign banks}

\subsection{The literature on foreign bank entry}

Over the last two decades foreign direct investment in banking has drawn substantial theoretical and empirical attention and Williams (1997) provides a comprehensive survey of the theoretical literature. However, the literature on the market share of the foreign banks is sparse and almost entirely cross-sectional in nature.

Walter (1992) makes the argument that bank-oriented financial systems (in contradistinction to market-oriented ones) are hostile to new entry, whether that of banks 
or markets. In line with Walter's argument, Steinherr and Huveneers (1994) provide evidence that foreign bank penetration of loan markets is lower in countries where a small number of domestic banks dominate the banking sector. In such environments the armslength loan market is stunted and domestic firms form relationships with the dominant domestic banks. With only a limited arms-length market on the one hand and an absence of relationships with domestic firms on the other, foreign banks have little scope for lending. Yafeh and Yosha (1995) propose a model in which domestic banks respond to foreign bank entry by increasing the resources that the domestic banks devote to the formation of ties with firms. The decline in the number of relationships with banks among Norwegian stock-exchange listed companies as bank deregulation progressed that Smith and Ongena (1997a) report is consistent with this argument.

The foreign banks' small market share in the Nordic countries is consistent with that of foreign banks in Japan (2-3\%; Tschoegl 1988). Japan and the Nordic countries are mature banking markets where the existing domestic banks are large and well-established. Also all have bank-oriented financial systems.

A small number of studies do look at the evolution of the size of the foreign bank sector over time. Tschoegl (1988) points out that foreign banks' share of banking system assets was high at the beginning of the opening of Japan in the mid- $19^{\text {th }}$ Century and again immediately after World War II before declining, but he does not model the decline. Williams (1996) looked at the performance of Japanese banks in Australia following Australia's removal of its entry restrictions. He found that the foreign banks' market share peaked some eight years after entry. However, the falling share of the Japanese banks 
coincided with the domestic problems of the Japanese banks and their customers in the 1990s, problems that may have resulted in some retrenchment for both.

As far as entry per se is concerned, the existing literature on entry of new firms makes much of the liability of newness -- the need to establish organizational routines (Baum, 1996). However, in the case of entry by foreign banks, the parents of the entrants are wellestablished firms. The ventures themselves are new, but the organizations of which they are a part are not. Tschoegl (1982), Tschoegl (1983), Ball and Tschoegl (1985), Tschoegl (1988), Ursacki and Vertinsky (1992) and Williams (1996) all provide evidence that the banks that engage in FDI are large and generally have extensive experience with foreign direct investment.

However, the new ventures are foreign and this means that they must face the challenge of the liability of foreignness. This liability has three aspects. The first of these is that the new entrant faces the cost of operating at a distance and must learn a new environment. These issues have been part of the literature on FDI since Hymer's (1960) seminal thesis and are an important part of other subsequent theoretical papers such as Kindleberger (1969), Buckley and Casson (1976), Caves (1982) and Hennart (1982). However, operating at a distance does not appear to be a major source of problems in FDI in banking (Engwall 1992). Several studies such as those of Choi et al., (1986 and 1996) that look at financial centers find no effect of distance on FDI in banking. Distance could have an indirect effect on FDI in banking. To the degree that banks follow trade and their customers, and that these fall off with distance so will FDI in banking. Thus one should not be surprised at the absence of Japanese banks in the Nordic countries, and one should expect to see banks from Europe and the other Nordic countries. 
The problems of operating in an unfamiliar environment is a different case. As Caves (1982) has argued, these would be most severe in horizontal FDI where the foreign firms are competing with local firms for a share of the host country market. Thus the liability of foreignness would be least critical in financial centers, especially offshore centers, and most critical in retail markets. Tschoegl (1987) argues that it is precisely for these reasons that, ethnic banking aside, that we see so little FDI in retail banking. Obviously, the liability of foreignness, even in retail banking, should be least for other Scandinavian banks given the shared national histories and cultures, and the highly similar languages. Even for a Finnish bank such as the Union Bank of Finland (now part of MeritaNordbanken), a bank historically of and for the Swedish commercial community in Finland, Scandinavia would not be alien.

Zaheer and Mosakowski (1997) have the only micro study of the liability of foreigness that we are aware of. They studied the entry and survival of banks' foreign exchange trading rooms and found that the liability of foreignness changed over time. In the first two years, the survival rate of host-country and foreign-owned trading rooms were similar; this suggests that the liability of newness is initially about the same magnitude as the liability of foreignness. For the next fourteen years, foreign-owned trading rooms owned by foreign banks exited at a higher rate than those owned by hostcountry banks; the exit rate peaked at eight years.

The third aspect of the liability of foreigness, and one that is particularly critical in banking, is that the new entrant must establish relationships with clients (Engwall and Johanson 1990). As Kindleberger (1983) has argued, banks when they go abroad frequently follow their commercial and industrial customers or lead them abroad. In either 
case, the foreign bank is using existing relationships. Generally though, dealing only with home-country customers abroad will limit the foreign bank to a niche in the host country. If the foreign bank is to grow beyond that niche it must establish ties with host-country customers. Whether the foreign banks will be able to do so will depend on the competitive conditions in the host market.

There is no literature that connects the deregulation of domestic banking with the entry of foreign banks. Some articles do discuss the effect of banking deregulation on survival in the industry. Engwall and Johanson (1990) argue that deregulation will cause a transformation in existing networks of relationships between banks and their clients but not the importance of relationships. In their long-run analysis of banking in Sweden, Bergström et al., (1994) find that survival rates are negatively related to the freedom of bank operations and to the degree to which customer relationships already exist. That is, a more competitive environment hurts survival rates and banks that already have relationships with clients are more likely to survive.

\subsection{Three hypotheses}

The literature we have reviewed provides the basis for three hypotheses about the influences of learning, access to home-country related business, and the effect of impediments to the competitiveness of host-country banks.

First, we can expect the foreign banks to be subject both to selection and evolutionary learning (Baldwin and Rafiquzzaman 1995). Selection will cull many of the entrants. However, those entrants that survive should over time improve their performance relative to incumbent firms. The banks that enter do so in the expectation that they will succeed; 
risk and uncertainty mean that not all will survive. Those that do are likely to be the ones that correctly estimated that they could win share away from the incumbents. One can further argue that the survivors should on average do well enough to offset the losses of the unsuccessful entrants who have forfeited the sunk costs of entry (Lippman and Rumelt 1982). Williams' (1995) findings for Japanese banks in Australia suggests the possibility of a quadratic term. Given the questions about Williams' results and our lack of degrees of freedom, we have chosen to remain with a simple time trend.

H1: The longer foreign banks have been present, the larger their market share.

Second, we expect the foreign banks' market share of banking system assets in a country to correlate positively with imports to the country and negatively with exports (Heinkel and Levi 1992). Imports create a need for foreign bank services in the country. Exports give domestic banks an incentive to go abroad and thus provide domestic clients with a substitute source of some banking services to. Tschoegl (1988) has a small $(\mathrm{n}=8)$ cross-sectional regression that supports this argument.

H2: The market share of foreign banks should wax with a trade deficit and wane with a trade surplus.

Lastly, financial crises should correlate positively with an expanded role for the foreign banks. Less tied to the domestic economy, the foreign banks can expand their activities while the domestic banks react to the crisis by curtailing their lending. 
Furthermore, crises may remove regulatory barriers to the acquisition of local banks by foreign banks. There is, however, a counter-hypothesis due to Stiglitz and Weiss (1981). They argue that to get market share, the entrant has to underprice. Existing firms will match the price only for good clients. The entrant will, therefore, suffer from adverse selection and so in a crisis, may be worse hurt than the domestic firms. Which effect will dominate is therefore an empirical issue. For the US, the evidence in Deyoung and Nolle (1986) is that foreignowned banks may have placed growth ahead of profitability. Still, we will state our maintained hypothesis as:

H3: The foreign banks' market share should wax when domestic banks are facing loan losses and wane when the domestic banks are less burdened.

\subsection{Empirical tests}

\subsection{Methodology}

To test the three hypotheses we performed several OLS regressions for each country separately. The variability in the results below is a clear signal that pooling would be inappropriate. Absent pooling, we had limited degrees of freedom and so were unable to search over alternative specifications or to experiment with lags.

The market share data we use below, which we base on assets on the books of entities in the country, probably understates the foreign banks' market share in each Nordic country. Some foreign banks may be serving clients in each of the Scandinavian countries 
but from offices in London or other financial centers. This was certainly the case for Norway in the past and is the case for Chase Manhattan vis-à-vis Denmark.

Furthermore, as Tschoegl (1988) points out with respect to foreign banks in Japan, official statistics tend to cover traditional activities and to omit new ones. This is especially problematic as the new activities are more likely to represent activities where clients choose their bank on expertise in particular, specialized transactions rather than on the basis of credit relationships. Thus we have no information on the foreign banks' market share in foreign exchange markets, let alone in derivatives markets. A survey (Euromoney 1995) lists the top 5 banks in the Scandinavian currencies (globally) as: Skandinaviska Enskilda Banken, Svenska Handelsbanken, Den Danske Bank, Citibank and Chase Manhattan.

For each regression, we transformed the foreign banks' share of domestic banking system assets to the logit of the share. We did so to "bend" the dependent variable to obviate fitted values that exceeded 1 , or more probably for our data, that fell below 0 . For each of our four markets we set $\lambda$, the long-run asymptote, at just above the maximum share that the foreign banks have achieved in the market.

Our first independent variable was TIME, a simple time-trend to capture learning effects. We expected a positive coefficient.

The second independent variable was TRADE BALANCE, the natural logarithm of the ratio of each country's total exports to the country's total imports. Using the natural $\log$ ensures that balanced trade has no implications for market share. However, we further expected a negative coefficient; that is, we expected the foreign banks' market share to 
grow with imports and to decline with exports. Thus a trade surplus would imply a smaller market share for foreign banks than would a trade deficit.

The third independent variable was LOSSES, the system-wide ratio of loan-loss

write-offs to loans. We expected the coefficient to be positive; foreign banks may have gained market share as the need to deal with problem loans constrained the large domestic banks from competing aggressively for loans.

For a parallel regression for each country we further transformed the dependent and independent variables by standardizing them. This procedure enables us to talk about economic significance as we have transformed all the coefficients into so-called "beta coefficients" that have the same dimension. The absolute value of the size of the coefficient gives its relative importance in terms of its ability to explain the variation in the dependent variable. (The gain in comparability does cost us "naturalness" of the independent variables; for example, the standardized variable measures an increment in TIME as one standard deviation of the sample data rather than as a year.)

\subsection{Results}

Table 5 presents the results. For Denmark we set $\lambda=1.5 \%$. All three independent variables had the correct sign and all were statistically significant at the 5\% level. The beta coefficients from the regression on the standardized variables shows TIME as the most important variable and TRADE BALANCE having a larger effect than LOSSES.

For Finland we set $\lambda=10 \%$. TIME had the correct sign, but the other two variables had perverse signs. All three variables had a large effect in the sense that a one standard 
deviation change in the independent variable gave about a one standard deviation change in the dependent variable.

However, all these results were sensitive to our treatment of Handelsbanken's 1995 acquisition of Skopbank. We tried two methods to take this acquisition into account. First, we included a dummy variable (ACQUISITION) which took on a value of 1 in 1995 and 1997 (1996 market share data was unavailable) and 0 otherwise. The dummy variable proved to be the only important variable and the only one to have any statistically significant effect, although all coefficients retained their signs. Second, in a regression not in Table 5, we estimated the model while omitting 1995 and 1997, and with $\lambda=3 \%$; this too failed to improve the results. The coefficients on TIME and TRADE had perverse signs and LOSSES had the correct sign. Still, we could not reject the null hypothesis that the foreign banks' market share in Finland was uncorrelated with our explanatory variables.

For Norway we set $\lambda=4 \%$. TIME was the only important factor.

For Sweden too we set $\lambda=4 \%$. As the Table shows, TIME had a negative effect but was not an important factor. More interestingly, the foreign banks' market share waned when LOSSES were high and waxed when they were low. Also, the foreign banks' market share moved with the TRADE BALANCE rather than against it. Lastly, each of these two variables had a fairly large effect.

\subsection{Conclusion}

In all four Nordic countries, the survival rate among the initial foreign entrants appears low. From peak to trough, the number of foreign banks fell by a third to a half, 
depending on the country. Since then though in Finland and Sweden the number has now rebounded to a new peak. Denmark and Norway have seen more modest rebounds. Furthermore, in all four countries, the market share of the foreign banks increased over time. Also, the rank of the largest foreign bank has increased. One cannot make too much of this; a simple Gibrat (stochastic growth) process with an absorbing barrier on the left would tend to give this result (Sutton 1997). Furthermore, the growth is due in large part to acquisition.

These observations are consistent with at least one of Geroski's (1995) stylized facts and results about entry. For instance, Geroski's stylized fact number 4 states that "The survival rate of most entrants is low and even successful entrants may take more than a decade to achieve a size comparable to the average incumbent." This congruence between our results and those of other entry studies is striking in that our entrants are not new firms in the same sense as in most of those studies. This suggests that the liability of foreignness may be as great a handicap as the liability of newness.

Still, the issue in this paper is not survival of individual banks but rather the evolution of the penetration of the foreign banks. Absent acquisitions of domestic banks, the foreign banks have not carved out a large role in any of the four Nordic countries. This result is consistent with what we would expect from theory based on the role of relationships in banking and from Steinherr and Huveneer's (1994) argument and empirical results.

In our data, the results for Denmark conformed with our expectations. The results for Finland and Norway were indeterminate. The results for Sweden were perverse. The difference is congruent with differences in the elapsed time since opening; to 
recapitulate, the order of opening to foreign banks was Denmark, Finland, Norway and Sweden. The results are not strong enough for us to more than conjecture that the reason may be changes in the identities and motives of the entrants over time.

As far as the link to trade is concerned, the results were mixed. The foreigners' share moved against the balance (as expected) in Denmark and Norway, and with the balance (contrary to expectations) in Finland and Sweden.

Lastly, except in Denmark, the foreign banks' share of domestic banking system assets waxed and waned as the domestic banks waxed and waned. There is anecdotal evidence (Korea Herald 24 Feb 1999) that the foreign banks came to dominate wholesale banking in Finland during the crisis, but that will not show up in our data. In Finland, Norway and Sweden, the foreign banks lost aggregate market share even as the domestic banks suffered loan losses. This is consistent with the Stiglitz-Weiss argument that the new entrants may have to take on less creditworthy customers on their books as they seek to establish themselves. They were then caught out when the crisis came.

Today we are seeing an increase in cross-border mergers and acquisition in banking. Our results and the questions they raise constitute a call for further research on this increasingly important phenomenon. 


\section{References}

Baldwin, John R. and Mohammed Rafiquzzaman. 1995. Selection versus evolutionary adaptation: Learning and post-entry performance. International Journal of Industrial Organization 13 (4), 501-522.

Ball, Clifford A., and Adrian E. Tschoegl. 1982. The Decision to Establish a Foreign Bank Branch or Subsidiary: An Application of Binary Classification Procedures. Journal of Financial and Quantitative Analysis 17 (3), 411-424.

Ball, M. 1994. The 1980s property boom. Environment and Planning A 26, 671-695.

Bartholomew, Philip F. 1994. Comparing Depository Institution Difficulties in Canada, the United States, and the Nordic Countries. Journal of Housing Research 5 (2), 303- 309.

Baum, Joel A. C. 1996. Organizational Ecology. In Stewart R. Clegg, Cynthia Hardy \& Walter R. Nord, eds. Handbook of Organization Studies (London: Sage).

Berg, Sigbjørn Atle, Finn R. Førsund, Lennart Hjalmarsson and M. Suominen. 1993. Banking efficiency in the Nordic Countries. Journal of Banking and Finance 17 (2-3): 371 388.

Berg, Sigbjørn Atle, Finn R. Førsund and Eilev S. Jansen. 1992. Malmquist Indices of Productivity Growth during the Deregulation of Norwegian Banking, 1980-1989. Scandinavian Journal of Economics 94, Supplement 211-228.

Bergström, Reinhold, Lars Engwall and Eva Wallerstedt. 1994. Organizational foundations and closures in a regulated environment: Swedish commercial banks 18311990. Scandinavian Journal of Management 10 (1): 29-48.

Børsen (Copenhagen). 1992, 3 January. p. 18.

Buckley, Peter J. and Mark Casson. 1976. The Future of the Multinational Enterprise (London: MacMillan).

Caprio, Gerard Jr., and Daniela Klingebiel. 1996. Bank Insolvencies: Cross Country Experience. Policy Research Department, The World Bank, unpublished paper.

Caves, Richard E. 1982. Multinational enterprise and economic analysis. (New York: Cambridge University Press).

Choi Sang-Rim, Adrian E. Tschoegl, Yu Chwo-Ming. 1986. Banks and the World's Major Financial Centers, 1970-1980. Weltwirtschaftliches Archiv 122 (1): 48-64. 
----, Park Daekun and Adrian E. Tschoegl. 1996. Banks and the World's Major Banking Centers, 1990. Weltwirtschaftliches Archiv 132 (4): 774-793.

DeYoung, Robert and Daniel E. Nolle. 1996. Foreign-owned banks in the United States: Earning Market Share or Buying It? Journal of Money, Credit and Banking 28: 622-636.

Engwall, Lars. 1992. Barriers in International Banking Networks. In: Mats Forsgren and Jan Johanson, eds. Managing Networks in International Business (Philadelphia: Gordon \& Breach), 167-177.

----. 1994. Bridge, Poker and Banking. In Donald E. Fair and Richard Raymond, eds. The Competitiveness of Financial Institutions and Centres in Europe (Dordrect: Kluwer).

----. 1997. The Swedish Banking Crisis. The Invisible Hand Shaking the Visible Hand. In David Knights and Glenn Morgan, eds. Regulation and Deregulation in European Financial Services (London: Macmillan).

----, and Jan Johanson. 1990. Banks in Industrial Networks. Scandinavian Journal of Management 6 (3), 231-244.

Treasurers put their views on banks. Euromoney. May 1995, 65-84.

Awards for Excellence 1997. Euromoney.July 1997, 69-118.

Finans and Samfund, March 1993, no. 3. Copenhagen Samfund.

Geroski, P.A. 1995. What do we know about entry? International Journal of Industrial Organization 13 (4), 421-440.

Heinkel, Robert L., and Maurice D. Levi. 1992. The structure of international banking. Journal of International Money and Finance 16 (2), 251-272.

Hennart, Jean-François. 1982. A Theory of Multinational Enterprise (Ann Arbor: Univ. of Michigan Press).

Hymer, Stephen H. 1960. The International Operations of National Firms: A Study of Direct Investment (Cambridge, MA: MIT Press; 1976).

Jacobsen, Siv Fagerland and Adrian E. Tschoegl. 1999. The Norwegian Banks in the Nordic Consortia: A Case of International Strategic Alliances in Banking. Industrial and Corporate Change 8 (1): (forthcoming).

Kindleberger, Charles P. 1969. American Business Abroad. (New Haven: University Press). 
----. 1983. International Banks as Leaders or Followers of International Business. Journal of Banking and Finance 7, 583-595.

----. 1995. Asset Inflation and Monetary Policy. Banca Nazionale del Lavoro Quarterly Review 48 (no. 182), 17-38.

Koskenkylä, Heikki. 1994. The Nordic Banking Crisis. Suomen Pankki Monthly Bulletin 68 (8), 15-22.

Lindblom, Ted. 1994. Credit Losses in Nordic Banks. In Jack Revell, ed. The Changing Face of European Banks and Securities Markets (London: St. Martins Press).

Lippman, Samuel A. and Richard P. Rumelt. 1982. Uncertain imitability: an analysis of interfirm differences in efficiency under competition. Bell Journal of Economics 13 (3), 418-38.

Ministry of Industry. 1992. Fremtidens Finansielle Sektor (The Future of the Financial Sector.) Copenhagen.

Møller, Michael and Niels Chr. Nielsen. 1995. Some observations on the Nordic Banking Crisis: A Survey. Institut for Finansiering, Handelshøjskolen I Kobenhaven, unpublished paper.

Nordström, Kjell A. and Jan-Erik Vahlne. 1994. Is the Globe Shrinking? Psychic Distance and the Establishment of Swedish Sales Subsidiaries during the Last 100 Years. In Michael Landeck, ed. International Trade: Regional and Global Issues. (New York: St. Martin's Press).

OECD. 1984. International Trade in Services: Banking (Paris: OECD)

Ongena, Steven and David Smith. 1997a. Empirical Evidence on the Duration of Bank Relationships. Norwergian School of Management Discussion Paper \#3-1997.

Ongena, Steven and David Smith. 1997b. Quality and Duration of Bank Relationships. Norwegian School of Management, unpublished paper.

Otholm, Carl A., Kim Busck-Nielsen, Kai Hammer-Pedersen and Peter Engbjerg Jensen. 1994. Dansk bankvasen: i dag - i morgen ("The Danish Banking Sector: today and tomorrow"). (Copenhagen: FSRs Publishing.)

Østrup, Finn. 1989. Det finansielle system i Danmark ("The Financial System in Denmark"). (Copenhagen: Jurist-og Økonomforbundets Forlag.)

Pauli, Ralf. 1984. Establishment of Foreign Banks in Finland: Background and Experiences. Bank of Finland Bulletin 58 (4), 1-2\&38. 
Rautava, Jouko. 1994. The Finnish Experience with Financial Liberalization: Some Lessons for Economies in Transition. In John P. Bonin and Istvan P. Szekely, eds. The Development and Reform of Financial Systems in Central and Eastern Europe. (Brookfield, Vermont: Edward Elgar).

Rinde, Jon. 1986. The cost level in Norwegian banks compared with banks in other countries. Norwegian Commercial Banks Financial Review 60 (3), 1-5.

Saavela, Juha and Risto Herrala. 1992. Foreign-owned banks in Finland. Bank of Finland Bulletin 66 (4), 8-12.

Shaffer, Sherrill. 1994. Market Conduct and Aggregate Excess Capacity in Banking: A Cross-Country Comparison. Federal Reserve Bank of Philadelphia Working Paper No. 93-26.

Statistics Sweden. Various years. Bankerna (The Banks) and Finansiella företag (Financial enterprises).

Steinherr, A. and C.H. Huveneers. 1994. On the performance of differently regulated financial institutions: Some empirical evidence. Journal of Banking and Finance 18 (2), 271-306.

Stiglitz, J. E. and A. Weiss. 1981. Credit Rationing with Imperfect Information. American EconomicReview 71 (3): 393-410.

Sutton, John. 1997. Gibrat's Legacy. Journal of Economic Literature 35: 40-59.

Swedish Banker's Association. 1998. The Emergence of one Scandinavian Banking Market (Framväxten av en skandinavisk bankmarknad).

Tschoegl, Adrian E. 1982. Foreign Direct Investment in Banking in Japan and California. 1982. In Alan Rugman, ed., New Perspectives on the Multinational Enterprise: Theory and Applications, (London: Croom Helm Ltd.).

----. 1983. Size, Growth and Transnationality Among the World's Largest Banks. Journal of Business 56 (2): 187-201.

----. 1985. Ideology and Changes in Regulations: The Case of Foreign Bank Branches Outside the U.S. Over the Period 1920-1980. In Brewer, Thomas L., ed., Political Risks in International Business (New York: Praeger).

----. 1987. International retail banking as a strategy: An assessment. Journal of International Business Studies 19 (2), 67-88. 
----. 1988. Foreign Banks in Japan. Bank of Japan Monetary and Economic Studies 6, 1, 93-118.

Ursacki, Terry, and Ilan Vertinsky. 1992. Choice of entry timing and scale by foreign banks in Japan and Korea. Journal of Banking and Finance 16 2, 405-421.

Vastrup, Claus. 1983. Economic Motives for Foreign Banking: The Danish Case. Kredit und Kapital 16 (1): 117-25.

Wallenberg, Marcus. c. 1920. The Reciprocal Treatment of Branches of Foreign Banks in Different Countries (League of Nations: Provisional Economic and Financial Committee).

Walter, Ingo. Winter 1992. "The Battle of the Systems: Control of Enterprises and the Global Economy," Journal of International Securities Markets 6: 309-317.

Williams, Barry. 1996. Determinants of the performance of Japanese financial institutions in Australia 1987-1992. Applied Economics 28, 1153-1165.

----. 1997. Positive theories of multinational banking: eclectic theory versus internalization theory. Journal of Economic Surveys 11 (1), 71-101.

Yafeh, Yishay and Oved Yosha. Nov. 1995. The Strategic Use of Relationship Banking. Hebrew University, Dept. of Economics, Working Paper 308.

Zaheer, Sri and Elaine Mosakowski. 1996. The Dynamics of the Liability of Foreigness: A Global Study of Survival in Financial Services. Strategic Management Journal 18 (6): 43964. 
Table 1

Between 1971 and 1990, the number and the market share of foreign banks in Denmark grew, waned and then stabilized at a low level

\begin{tabular}{|c|c|c|c|c|c|c|c|}
\hline \multirow{3}{*}{$\underline{\text { Year }}$} & \multirow{3}{*}{$\underline{\mathrm{L} / \mathrm{L}}$} & & & & \multirow{3}{*}{$\begin{array}{l}\text { Market Share } \\
\text { Foreign }\end{array}$} & \multicolumn{2}{|c|}{ Largest foreign bank } \\
\hline & & \multicolumn{3}{|c|}{ Number of banks } & & $\underline{\text { Rank }}$ & Name \\
\hline & & Total & Dom. & Foreign & & & \\
\hline 1970 & $1.2 \%$ & 90 & 90 & 0 & $0.0 \%$ & & \\
\hline 1971 & $1.0 \%$ & 82 & 81 & 1 & $0.0 \%$ & & \\
\hline 1972 & $1.2 \%$ & 82 & 81 & 1 & $0.1 \%$ & 71 & American Express \\
\hline 1973 & $2.2 \%$ & 81 & 80 & 1 & $0.1 \%$ & 67 & American Express \\
\hline 1974 & $2.6 \%$ & 79 & 78 & 1 & $0.1 \%$ & 64 & American Express \\
\hline 1975 & $1.3 \%$ & 82 & 79 & 3 & $0.1 \%$ & 61 & American Express \\
\hline 1976 & $0.6 \%$ & 83 & 78 & 5 & $0.5 \%$ & 48 & Bank of America \\
\hline 1977 & $0.9 \%$ & 81 & 76 & 5 & $0.9 \%$ & 30 & Bank of America \\
\hline 1978 & $1.2 \%$ & 81 & 76 & 5 & $1.0 \%$ & 32 & Chase Manhattan \\
\hline 1979 & $1.3 \%$ & 82 & 77 & 5 & $1.1 \%$ & 28 & Chase Manhattan \\
\hline 1980 & $2.0 \%$ & 81 & 76 & 5 & $1.2 \%$ & 28 & Chase Manhattan \\
\hline 1981 & $2.6 \%$ & 80 & 75 & 5 & $1.3 \%$ & 22 & Chase Manhattan \\
\hline 1982 & $3.5 \%$ & 80 & 75 & 5 & $1.4 \%$ & 20 & Chase Manhattan \\
\hline 1983 & $3.0 \%$ & 81 & 74 & 7 & $1.2 \%$ & 25 & Chase Manhattan \\
\hline 1984 & $2.1 \%$ & 80 & 72 & 8 & $1.2 \%$ & 25 & Chase Manhattan \\
\hline 1985 & $2.3 \%$ & 80 & 72 & 8 & $0.9 \%$ & 28 & Chase Manhattan \\
\hline 1986 & $0.9 \%$ & 82 & 73 & 9 & $0.9 \%$ & 29 & Chase Manhattan \\
\hline 1987 & $1.4 \%$ & 81 & 74 & 7 & $0.7 \%$ & 35 & Chase Manhattan \\
\hline 1988 & $2.1 \%$ & 82 & 74 & 8 & $0.8 \%$ & 26 & Citibank \\
\hline 1989 & $1.9 \%$ & 80 & 72 & 8 & $0.8 \%$ & 23 & Citibank \\
\hline 1990 & $2.5 \%$ & 76 & 68 & 8 & $0.9 \%$ & 16 & ABN-AMRO \\
\hline 1991 & $2.6 \%$ & 74 & 66 & 8 & & & \\
\hline 1992 & $3.2 \%$ & 70 & 63 & 7 & & & \\
\hline 1993 & $3.0 \%$ & 70 & 62 & 8 & & & \\
\hline 1994 & $1.6 \%$ & 71 & 63 & 8 & & & \\
\hline 1995 & $1.2 \%$ & 70 & 64 & 6 & & & ABN-AMRO \\
\hline 1996 & $0.7 \%$ & 67 & 60 & 7 & & & \\
\hline 1997 & & & & 7 & & & ABN-AMRO (1) \\
\hline
\end{tabular}

Note: L/L represents Losses to Loans. Boldface indicates a peak. (1) Based on data for the number of employees. Svenska Handelsbanken is the next largest with half as many employees.

Source: Danish Financial Supervisory Authority, Statistics on the Banking Sector, 1970 to 1997. 
$\underline{\text { Table } 2}$

Between 1982 and 1995, the number and the market share of foreign banks in Finland has waxed and waned; the recent acquisition by Handelsbanken has caused a leap in the foreign banks' market share

\begin{tabular}{|c|c|c|c|c|c|c|c|}
\hline \multirow{3}{*}{ Year } & \multirow{3}{*}{$\underline{\mathrm{L} / \mathrm{L}}$} & & & & \multirow{3}{*}{$\begin{array}{l}\text { Market Share } \\
\text { Foreign }\end{array}$} & \multicolumn{2}{|c|}{ Largest foreign bank } \\
\hline & & \multicolumn{3}{|c|}{ Number of banks } & & \multirow{2}{*}{ Rank } & \multirow{2}{*}{ Name } \\
\hline & & Total & $\underline{\text { Dom. }}$. & Foreign & & & \\
\hline 1980 & $0.0 \%$ & 7 & 7 & & & & \\
\hline 1981 & $0.0 \%$ & 7 & 7 & & & & \\
\hline 1982 & $0.0 \%$ & 7 & 7 & & & n.a. & n.a. \\
\hline 1983 & $0.0 \%$ & 10 & 7 & 3 & $2.3 \%$ & n.a. & n.a. \\
\hline 1984 & $0.1 \%$ & 10 & 7 & 3 & $1.8 \%$ & 7 & Citibank \\
\hline 1985 & $0.1 \%$ & 10 & 7 & 3 & $1.2 \%$ & 8 & Citibank \\
\hline 1986 & $0.2 \%$ & 11 & 7 & 4 & $1.0 \%$ & 6 & Citibank \\
\hline 1987 & $0.3 \%$ & 10 & 6 & 4 & $1.9 \%$ & 6 & Citibank \\
\hline 1988 & $0.4 \%$ & 11 & 7 & 4 & $1.3 \%$ & 7 & Citibank \\
\hline 1989 & $0.6 \%$ & 14 & 10 & 4 & $1.0 \%$ & 8 & Midland Montagu \\
\hline 1990 & $0.6 \%$ & 14 & 10 & 4 & $0.9 \%$ & 9 & Nordbanken \\
\hline 1991 & $1.9 \%$ & 17 & 12 & 5 & $1.3 \%$ & 9 & Handelsbanken \\
\hline 1992 & $4.5 \%$ & 14 & 10 & 4 & $1.5 \%$ & 9 & Handelsbanken \\
\hline 1993 & $4.9 \%$ & 13 & 10 & 3 & $1.1 \%$ & 7 & Handelsbanken \\
\hline 1994 & $3.4 \%$ & 13 & 10 & 3 & $2.5 \%$ & 7 & Handelsbanken \\
\hline 1995 & $2.1 \%$ & 12 & 8 & 4 & $9.6 \%$ & 4 & Handelsbanken \\
\hline 1996 & $1.6 \%$ & 12 & 8 & 4 & n.a. & 4 & Handelsbanken \\
\hline 1997 & $0.8 \%$ & 14 & 8 & 6 & $10.8 \%$ & 4 & Handelsbanken \\
\hline
\end{tabular}

Note: L/L represents Losses to Loans. Boldface indicates a peak.

Source: 
$\underline{\text { Table } 3}$

Since their entry in 1985, the foreign banks in Norway have increased their market share and their rank despite the fall in their numbers

\begin{tabular}{|c|c|c|c|c|c|c|c|}
\hline \multirow{3}{*}{ Year } & \multirow{3}{*}{$\underline{\mathrm{L} / \mathrm{L}}$} & & & & \multirow{3}{*}{$\begin{array}{l}\text { Market Share } \\
\text { Foreign }\end{array}$} & \multicolumn{2}{|c|}{ Largest foreign bank } \\
\hline & & \multicolumn{3}{|c|}{ Number of banks } & & \multirow[t]{2}{*}{$\underline{\text { Rank }}$} & \multirow{2}{*}{ Name } \\
\hline & & $\underline{\text { Total }}$ & Dom. & Foreign & & & \\
\hline 1980 & $0.9 \%$ & 24 & 24 & & & & \\
\hline 1981 & $1.0 \%$ & 22 & 22 & & & & \\
\hline 1982 & $1.0 \%$ & 22 & 22 & & & & \\
\hline 1983 & $1.1 \%$ & 21 & 21 & & & & \\
\hline 1984 & $1.0 \%$ & 21 & 21 & & & & \\
\hline 1985 & $1.0 \%$ & 27 & 20 & 7 & $0.6 \%$ & 19 & Citibank \\
\hline 1986 & $1.1 \%$ & 28 & 20 & 8 & $1.0 \%$ & 19 & Manufacturers Hanover \\
\hline 1987 & $1.3 \%$ & 28 & 20 & 8 & $1.4 \%$ & 15 & Manufacturers Hanover \\
\hline 1988 & $2.0 \%$ & 29 & 20 & 9 & $1.8 \%$ & 14 & Manufacturers Hanover \\
\hline 1989 & $2.1 \%$ & 29 & 21 & 8 & $1.5 \%$ & 16 & Manufacturers Hanover \\
\hline 1990 & $2.6 \%$ & 26 & 17 & 9 & $2.6 \%$ & 11 & Svenska Handelsbanken \\
\hline 1991 & $5.5 \%$ & 21 & 12 & 9 & $3.8 \%$ & 7 & Svenska Handelsbanken \\
\hline 1992 & $3.1 \%$ & 21 & 13 & 8 & $3.6 \%$ & 7 & Handelsbanken \\
\hline 1993 & $2.1 \%$ & 20 & 15 & 5 & $3.3 \%$ & 7 & Handelsbanken \\
\hline 1994 & $0.1 \%$ & 20 & 14 & 6 & $3.9 \%$ & 7 & Handelsbanken \\
\hline 1995 & $-0.4 \%$ & 18 & 13 & 5 & $3.7 \%$ & 6 & Handelsbanken \\
\hline 1996 & $-0.1 \%$ & 19 & 14 & 5 & $3.5 \%$ & 6 & Chase Manhatten \\
\hline 1997 & $0.0 \%$ & 22 & 14 & 8 & $5.8 \%$ & 7 & SEBanken \\
\hline
\end{tabular}

Note: L/L represents Losses to Loans. Boldface indicates a peak.

Source: Norwegian Bankers' Association, Norwegian Commercial Banks, 1980 to 1997 


\section{Table 4}

After 1987, the market share of the foreign banks in Sweden slipped dramatically before recovering

\begin{tabular}{|cccccccc}
\hline Year & L/L & & & & \multicolumn{3}{c}{ Largest foreign bank } \\
& & $\underline{\text { Total }}$ & $\begin{array}{c}\text { Number } \\
\text { Dom. }\end{array}$ & $\begin{array}{c}\text { Foreign } \\
\text { Nank }\end{array}$ & $\begin{array}{c}\text { Market Share } \\
\text { Foreign }\end{array}$ & \\
1980 & $0.2 \%$ & 14 & 14 & 0 & $0 \%$ & & \\
1981 & $0.2 \%$ & 14 & 14 & 0 & $0 \%$ & & \\
1982 & $0.7 \%$ & 14 & 14 & 0 & $0 \%$ & & \\
1983 & $0.6 \%$ & 14 & 14 & 0 & $0 \%$ & & \\
1984 & $0.8 \%$ & 15 & 15 & 0 & $0 \%$ & & \\
1985 & $0.5 \%$ & 15 & 15 & 0 & $0 \%$ & & \\
1986 & $0.6 \%$ & 26 & 14 & 12 & $3.0 \%$ & 12 & Den norske Creditbank \\
1987 & $0.5 \%$ & 25 & 14 & 11 & $\mathbf{3 . 8 \%}$ & 12 & Banque National de Paris \\
1988 & $0.3 \%$ & 23 & 14 & 9 & $3.1 \%$ & 12 & Den norske Creditbank \\
1989 & $0.3 \%$ & 24 & 14 & 10 & $3.1 \%$ & 12 & Société Générale \\
1990 & $1.1 \%$ & 17 & 10 & 7 & $1.9 \%$ & 8 & Société Générale \\
1991 & $3.6 \%$ & 14 & 8 & 6 & $1.3 \%$ & 7 & Banque Indosuez \\
1992 & $4.6 \%$ & 15 & 9 & 6 & $1.2 \%$ & 7 & ABN AMRO \\
1993 & $\mathbf{6 . 4 \%}$ & 15 & 9 & 6 & $2.0 \%$ & 7 & ABN AMRO \\
1994 & $2.1 \%$ & 17 & 10 & 7 & $2.6 \%$ & 7 & ABN AMRO \\
1995 & $1.4 \%$ & 25 & 13 & 12 & $3.3 \%$ & 8 & ABN AMRO \\
1996 & $0.7 \%$ & 31 & 17 & 14 & $3.8 \%$ & 8 & ABN AMRO \\
1997 & $0.6 \%$ & $\mathbf{3 5}$ & $\mathbf{1 8}$ & $\mathbf{1 7}$ & $\mathbf{3 . 8 \%}$ & $\mathbf{6}$ & Den Danske Bank \\
\hline
\end{tabular}

Note: L/L represents Losses to Loans. Boldface indicates a peak.

Source: Swedish Bankers Association 


\section{Table 5}

Our results were strongly in accordance with expectations in the cases of Denmark, mixed or indeterminate for Finland (once we adjust for the acquisition of Skopbank) and Norway, and strongly opposite in the case of Sweden.

\begin{tabular}{|c|c|c|c|c|c|}
\hline \multicolumn{6}{|c|}{ (t-statistics in parentheses) } \\
\hline \multirow[b]{2}{*}{$\lambda$} & \multirow{2}{*}{$\begin{array}{c}\text { Denmark } \\
1.5 \%\end{array}$} & \multicolumn{2}{|c|}{ Finland } & \multirow{2}{*}{$\begin{array}{c}\text { Norway } \\
4 \%\end{array}$} & \multirow{2}{*}{$\begin{array}{c}\text { Sweden } \\
4 \%\end{array}$} \\
\hline & & $10 \%$ & $3 \%$ & & \\
\hline Constant & -8.33 & -593 & -104 & -815 & 141 \\
\hline & $(-4.06)$ & $(-2.77)$ & $(-0.549)$ & $(-3.25)$ & $(0.559)$ \\
\hline TIME & 0.435 & 0.298 & 0.051 & 0.409 & -0.071 \\
\hline & (4.20) & (2.76) & $(0.539)$ & $(3.25)$ & $(-0.556)$ \\
\hline TRADE BALANCE & -15.4 & 9.07 & 1.28 & -0.085 & 12.2 \\
\hline & $(-2.83)$ & (2.40) & $(0.399)$ & $(-0.028)$ & (1.77) \\
\hline LOSSES & 99.6 & -188 & -33.9 & -9.26 & -83.4 \\
\hline & $(2.45)$ & $(-4.04)$ & $(-0.673)$ & $(-0.426)$ & $(-3.42)$ \\
\hline ACQUISITION & & & $\begin{array}{c}4.34 \\
\mathbf{( 3 . 8 3 )}\end{array}$ & & \\
\hline \multicolumn{6}{|l|}{ Beta coefficients } \\
\hline TIME & 1.40 & 1.13 & 0.194 & 1.03 & -0.192 \\
\hline TRADE BALANCE & -1.01 & 0.970 & 0.137 & -0.008 & 0.601 \\
\hline LOSSES & 0.423 & -1.35 & -0.244 & 0.098 & -0.673 \\
\hline | ACQUISITION & & & 1.39 & & \\
\hline $\mathrm{R}^{2}$ & 0.640 & 0.777 & 0.915 & 0.756 & 0.729 \\
\hline Adjusted $\mathrm{R}^{2}$ & 0.572 & 0.710 & 0.877 & 0.675 & 0.627 \\
\hline SER & 1.21 & 1.02 & 0.665 & 1.08 & 0.813 \\
\hline $\mathrm{F}$ & 9.46 & 11.6 & 24.2 & 9.29 & 7.18 \\
\hline NOBS & 20 & 14 & 14 & 13 & 12 \\
\hline
\end{tabular}

